\title{
Практичне застосування індексу BRAAFF в діагностиці акральних меланоцитарних пухлин
}

\author{
М.С. Волошинович', А. Лаллас', Г.Є. Гірник', І.О. Блага' \\ 'Івано-Франківський національний медичний університет, Україна \\ 2Університет Арістотеля в Салоніках, Греція
}

\begin{abstract}
Анотація. Меланома - одна з найнебезпечніших пухлин у силу здатності до стрімкого непрогнозованого метастазування. Коли пухлина знаходиться на відкритих ділянках шкіри, можливість ї̈ своєчасної діагностики зростає, та при акральній локалізації меланома тривалий час може знаходитися поза увагою. Для покращення прогнозу хворих на акральну меланому необхідною умовою $є$ забезпечення ранньої діагностики, для якої слугує метод дерматоскопії. Її роль у діагностиці акрально розміщених пігментацій полягає в оцінці особливостей структури, яка, на відміну від невусів інших локалізацій, найчастіше проявляється у формі патернів паралельних борозен, волокон, решітчастих комірок та візерунку паралельних гребінців. Проте близько $1 / 3$ акральних меланом можуть складатися з нерегулярних дифузних пігментацій та інших компонентів, тому необхідним $\epsilon$ введення додаткових критеріїв, які змогли би знизити ймовірність діагностичних помилок. Результатом стало розроблення колективом вчених із різних країн індексу BRAAFF, що становить систему підрахунку балів шести змінних, які продемонстрували найвищу чутливість і специфічність щодо акральної меланоми. Такі предиктори, як іррегулярна плямистість, малюнок паралельних гребінців, асиметрія структур та кольору, дають позитивні бали, тоді як патерн паралельних борозен чи волокон — негативні. Діагноз акральної меланоми вважають вірогідним, якщо результат обчислень $\geq 1$. Використання індексу BRAAFF може значною мірою покращити якість і специфічність обстеження при його застосуванні в щоденній практиці. Також він $\epsilon$ корисним для лікарів, які лише починають свій професійний шлях, а відповідно, не володіють достатнім досвідом для впевненого призначення лікувальної тактики. У публікації наведено клінічний приклад використання алгоритмічного підходу в менеджменті хворого з акральними утворами на шкірі.
\end{abstract}

Ключові слова: меланома, невус, дерматоскопія.

Меланома - одна з найнебезпечніших пухлин у силу здатності до стрімкого непрогнозованого метастазування. В Україні, згідно з даними Національного канцер-реєстру, захворюваність на меланому у 2018-2019 рр. становила 7,9 випадка на 100 тис. населення. Частіше хворіють жінки, хоча різниця з чоловіками незначна: 8,4 та 7,4 відповідно. Коли пухлина знаходиться на відкритих ділянках шкіри, можливість їі своєчасної діагностики зростає, та при акральній локалізації меланома тривалий час може знаходитися поза увагою як лікаря, так і самого пацієнта. Акральна меланома (AM) - найпоширеніша форма меланоми серед представників негроїдної раси. На цей тип припадає до 80\% меланом у африканців і приблизно 40\% - пацієнтів азіатських країн. У пацієнтів європеоїдної раси меланома частіше розвивається в інших локалізаціях, тоді як на АМ припадає до 5\% утворень [1].

Для покращення прогнозу хворих на АМ необхідною умовою $\epsilon$ забезпечення ранньої діагностики, для якої слугує метод дерматоскопії. При правильному застосуванні ефективність огляду за допомогою дерматоскопа зростає у 9,0 раза порівняно з обстеженням неозброєним оком. Чутливість щодо меланоми шкіри становить 87\% порівняно з 69\% для макроскопічного обстеження, тоді як специфічність знаходиться на однаковому рівні. Метод дозволяє покращити показники виявлення без збільшення кількості випадків помилкової діагностики [2].

Роль дерматоскопії в діагностиці акрально розміщених пігментацій полягає в оцінці особливостей структури, яка, на відміну від невусів інших локалізацій, проявляється у формі патернів паралельних борозен, волокон, решітчастих комірок та візерунка паралельних гребінців, що вже може свідчити про ознаки переродження в AM [3, 4]. Патерн паралельних борозен утворений пігментованими лініями розміщених у глибині шкірних борозен (рис. 1). Візерунок волокон складається з компактно розташованої ниткоподібної пігментації, яка перетинає паралельні лінії шкірного малюнка (рис. 2). Структуру решітчастих комірок становлять пігментовані лінії, розміщені в товщі шкірних борозен, з'єднані між собою перпендикулярними перетинками з формуванням комірок (рис. 3). Візерунок паралельних гребінців утворений стрічкоподібною пігментацією, розміщеною в ділянці шкірних гребінців (рис. 4).
Вищезазначені патерни можуть бути представлені як в ізольованому вигляді, так і в різних варіаціях сполучень (рис. 5).

Проте подальші дослідження показали, що близько $1 / 3$ AM можуть проявлятися у формі нерегулярних дифузних пігментацій та інших ознак, тому необхідне введення додаткових критеріїв, які змогли би знизити ймовірність діагностичних помилок [5].

Для верифікації переліку та встановлення достовірності таких ознак проведене мультицентрове морфологічне дослідження, в якому взяли участь спеціалізовані центри діагностики раку шкіри в Австрії, Франції, Греції, Японії та Італії. Про-

Рисунок 1 Патерн паралельних борозен (Parallel furrow pattern). Дерматоскопія з використанням світлопровідної рідини

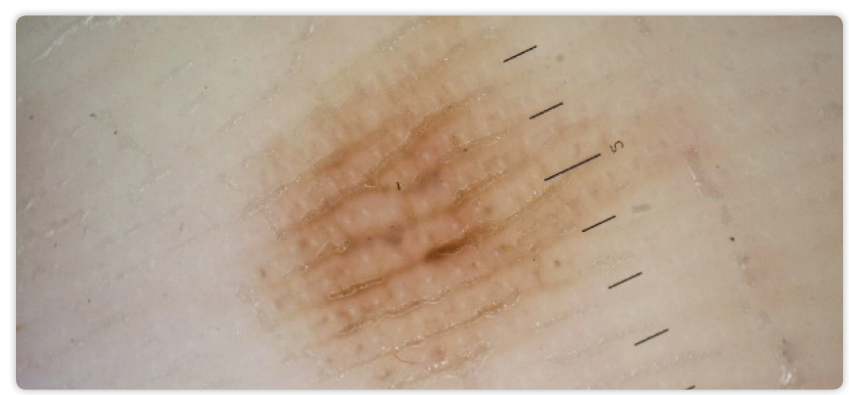

Рисунок 2 Патерн волокон (Fibrillar pattern). Дерматоскопія з використанням світлопровідної рідини 
аналізовано 603 акральні утворення, 3 них 472 - невуси та 131 - АM. Результатом стало розроблення індексу BRAAFF, що становить систему підрахунку балів шести змінних, які продемонстрували найвищу чутливість і специфічність щодо АМ. Такі предиктори, як іррегулярна плямистість, малюнок паралельних гребінців, асиметрія структур та кольору, дають позитивні бали, тоді як патерн паралельних борозен чи волокон - негативні (табл. 1).

Підрахунок здійснюють за формулою:

$$
B R A A F F=1(B)+3(R)+1(A)+1(A)-1(F)-1(F) .
$$

Бали нараховують лише у разі виявлення критерію в акральному утворенні, що оцінюється. Діагноз АМ вважають вірогідним, якщо результат обчислень $\geq 1$. За таких умов інтерпретації чутливість методу дерматоскопії щодо АМ досягла 93,1\%, специфічність - 86,7\% [6].

Та, незважаючи на алгоритмічний підхід, наявні додаткові фактори, які необхідно враховувати при встановленні діагнозу мела-

Рисунок 3 Патерн решітчастих комірок (Lattice-like pattern). Дерматоскопія з використанням світлопровідної рідини

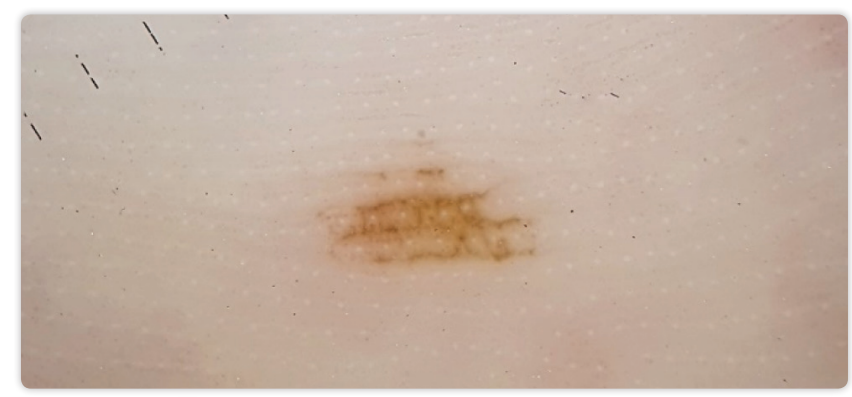

Рисунок 4 Патерн паралельних гребінців (Parallel ridge pattern). Дерматоскопія з використанням світлопровідної рідини

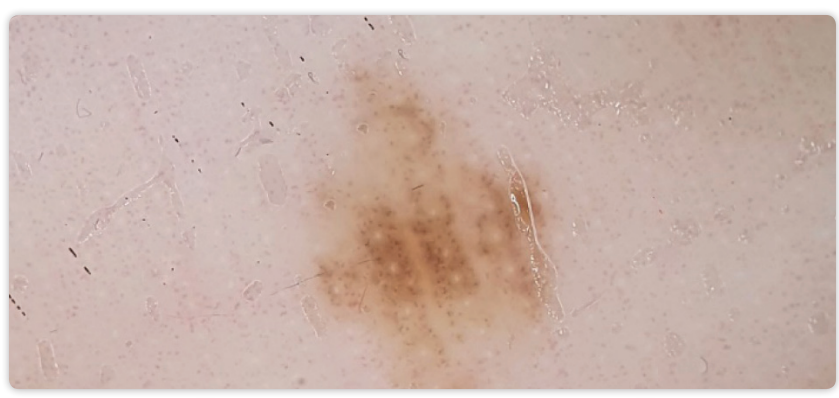

Рисунок 5 Сполучення патернів паралельних борозен та волокон. Дерматоскопія з використанням світлопровідної рідини

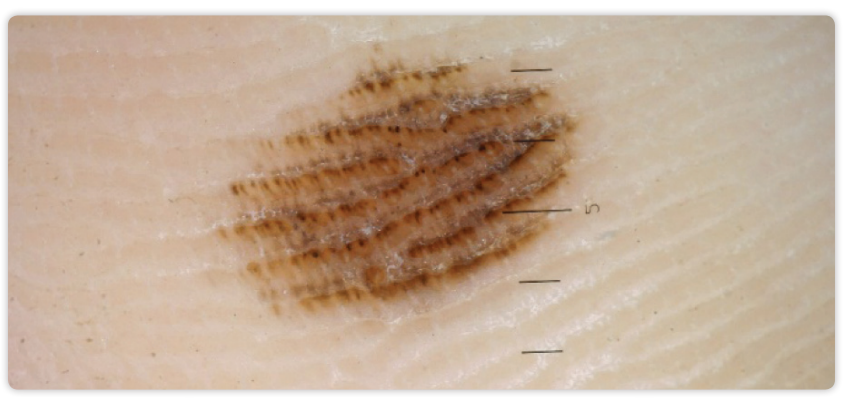

Таблиця Акронімічна інтерпретація індексу BRAAFF [6]

\begin{tabular}{clc}
\hline Акронім & \multicolumn{1}{c}{ Критерій } & Бали \\
\hline B & Іррегулярна плямистість (Irregular blotch) & +1 \\
\hline R & Малюнок паралельних гребінців (Parallel ridge pattern) & +3 \\
\hline A & Асиметрія структур (Asymmetry of structures) & +1 \\
\hline A & Асиметрія кольору (Asymmetry of colours) & +1 \\
\hline F & Патерн паралельних борозен (Parallel furrow pattern) & -1 \\
\hline F & Патерн волокон (Fibrillar pattern) & -1 \\
\hline
\end{tabular}

номи. Зокрема це - вік хворих: імовірність виявлення злоякісних пігментних перероджень в осіб дитячого та юнацького віку надзвичайно мала, переважно цей діагноз встановлюють у хворих віком >20 років [7].

Завдяки дерматоскопії отримано можливість диференціювання поміж акральним невусом та AM, базуючись на наявності у цих утворах двох різних візерунків, зумовлених накопиченням пігменту в ділянці борозен шкірного рельєфу (патерн паралельних борозен) та в ділянці шкірних гребенів (патерн шкірних гребінців). Гістопатологічно ці симптоми відповідають гніздам меланоцитів, локалізованих в ділянці crista profunda limitans, що типове для акрального невуса, та проліферації атипових меланоцитів, розміщених переважно навколо crista profunda intermedia, що відзначають при АМ. Тому варто особливо уважно ставитися до утворень з наявним малюнком паралельних гребенів як високоспецифічним для АМ та рекомендувати видалення утворень навіть у разі їх симетричності. Також він може бути відсутній при інвазивних меланомах, і в цій ситуації варто звернути увагу на інші сигнали щодо злоякісності.

Також не слід беззаперечно покладатися на доброякісні патерни (паралельних борозен чи волокон), оскільки вони можуть бути фокально наявні і у злоякісних утвореннях, тому необхідна оцінка утвору в цілому, а не інтерпретація його фрагментів [8].

Нерегулярна дифузна пігментація (іррегулярна плямистість) також описана як поширений дерматоскопічний критерій AM, що частіше вказує на інвазивні пухлини. Так само асиметрія кольорів та структур може бути підставою для ексцизійної біопсії навіть за умови виявлення супутніх позитивних предикторів [3, 4, 9].

Розглянемо приклад практичного застосування індексу BRAAFF у менеджменті акрального утвору.

\section{Клінічний випадок}

Хворий А., 1998 року народження.

Звернувся в дерматовенерологічний диспансер зі скаргами на наявність висипних елементів у ділянці лівої підошви, виявлених випадково під час самостійного огляду. Суб'єктивних відчуттів не викликали. Об'єктивно: у зазначеному місці дві плями неоднорідного коричневого кольору, неправильної та овальної форми, розміром близько 0,5х0,7 та 1,0×2,2 см (рис. 6).

Ad oculos: утвори неоднорідні за кольором та структурою. Хворий стверджує, що більший елемент був на шкірі протягом багатьох років, епізодів травматизації не пригадує, проте не заперечує імовірності тертя при носінні взуття. На менший елемент уваги не звертав, час його появи назвати не може.

При дерматоскопії пляма меншого розміру відносно симетрична, утворена пігментними глибками та ділянками дифузної пігментації, що формують стрічкоподібний малюнок, локалізований у проєкції шкірних гребенів (малюнок паралельних гребінців) (див. рис. 4). Утворення більшого розміру неоднорідне, з ознаками асиметрії за кольором та структурами. Представлене вираженою, різною за інтенсивністю забарвлення, стрічкоподібною пігментацією ділянки шкірних гребенів, яка поодиноко розшарована ділянками більш інтенсивного та вкрапленнями менш інтенсивного накопичення кольору в проєкції шкірних борозен, яка ніби розсуває навколишні структури, спотворюючи шкірний малюнок. Також визначаються хаотично розміщені гіперпігментні плями (рис. 7).

Щодо утворень проведено підрахунок індексу BRAAFF. Для меншого утворення, де наявний лише малюнок паралельних гребінців, його значення становило 3, для більшого, де, окрім того, наявні іррегулярна плямистість, малюнок паралельних гребінців, асиметрія структур та асиметрія кольору, - 6 .

Встановлено діагноз множинної АМ. Хворого скеровано на ексцизійну біопсію у зв'язку із специфікою виявлених дерматоскопічних патернів та результатами індексу BRAAFF >1. Діагноз підтверджено патогістологічно.

\section{Висновок}

Використання алгоритму BRAAFF може значною мірою покращити якість і специфічність обстеження при його застосу- 
Рисунок 6 Хворий А. Висипні елементи в ділянці лівої підошви. Макрофотографія

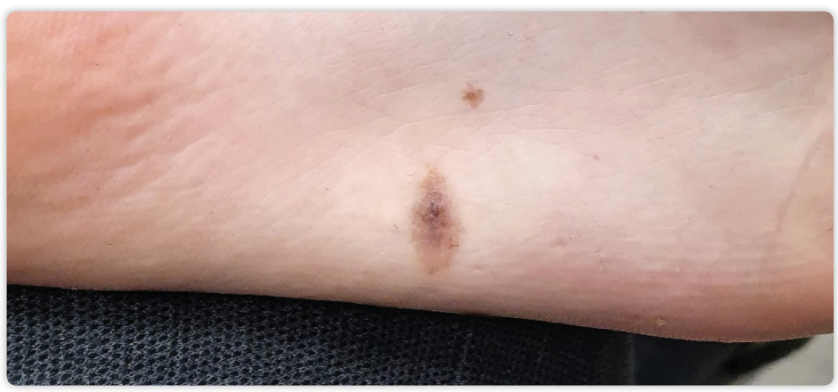

Рисунок 7 Хворий А. Утворення більшого розміру з ознаками асиметрії за кольором та структурами. Дерматоскопія з використанням світлопровідної рідини

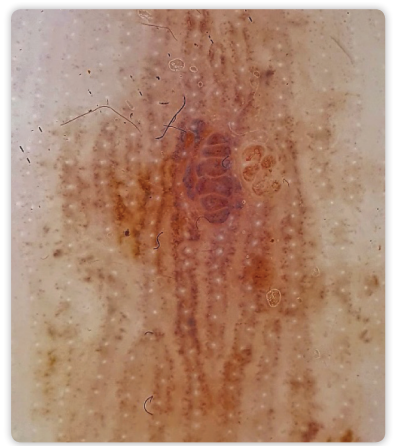

ванні у щоденній практиці. Особливо цінним він $є$ у тому разі, якщо остаточний діагноз викликає сумніви, дозволяючи схилити лікаря до певного рішення. Також він $є$ корисним для лікарів, що поки лише починають свій професійний шлях, i, відповідно, не володіють достатнім досвідом для впевненого призначення лікувальної тактики. Проте, застосовуючи його, не слід забувати про необхідність індивідуалізованого підходу, комплексної оцінки всіх доступних клінічних та анамнестичних даних, які можуть значною мірою впливати на прийняте рішення.

Конфлікт інтересів: відсутній.

Conflict of interests: the authors declare no conflict of interests.

Список використаної літератури/References:

1. Soyer H.P., Argenziano G., Hofmann-Wellenhof R., Johr R.H. (2007) Color atlas of melanocytic lesions of the skin. Springer, Berlin, Heidelberg. https://doi.org/10.1007/978-3-54035106-1

2. Lee K.J., di Meo N., Yélamos 0. et al. (2020) Dermoscopy/Confocal Microscopy for Melanoma Diagnosis. In: Balch C. et al. (Eds.) Cutaneous Melanoma. Springer, Cham. https://doi. org/10.1007/978-3-030-05070-2_50

3. Saida T., Koga H., Uhara H. (2011) Key points in dermoscopic differentiation between early acral melanoma andacral nevus.J.Dermatol.,38(1):25-34.https://doi.org/10.1111/j.1346-8138.2010.01174.x

\section{Відомості про авторів:}

Волошинович Мар'ян Стефанович — кандидат медичних наук, доцент кафедри дерматології та венерології Івано-Франківського національного медичного університету, Україна. ORCID ID: 0000-0001-7619-2289

Аміліос Лаллас — доктор філософії, професор Першого департаменту дерматології Університету Арістотеля, Салоніки, Греція. ORCID ID: 0000-0002-7193-0964

Гірник Галина Євгенівна — кандидат медичних наук, доцент кафедри дерматології та венерології Івано-Франківського національного медичного університету, Україна. ORCID ID: 0000-0002-9353-6490

Блага Ірина Олегівна — асистент кафедри дерматології та венерології Івано-Франківського національного медичного університету, Україна.

Адреса для кореспонденції:

Волошинович Мар'ян Стефанович

76018, Івано-Франківськ, вул. Кропивницького 16

E-mail: mvoloshynovych@gmail.com
4. Saida T., Miyazaki A., Oguchi S. et al. (2004) Significance of dermoscopic patterns in detecting malignant melanoma on acral volar skin: Results of a multicenter study in Japan. Arch. Dermatol., 140(10): 1233-1238. https://doi.org/10.1001/archderm.140.10.1233

5. Lallas A., Sgouros D., Zalaudek I. et al. (2014) Palmar and plantar melanomas differ for sex prevalence and tumor thickness but not for dermoscopic patterns. Melanoma Res., 24(1): 83-87. https://doi.org/10.1097/CMR.0000000000000037

6. Lallas A., Kyrgidis A., Koga H. et al. (2015) The BRAAFF checklist: A new dermoscopic algorithm for diagnosing acral melanoma. Br. J. Dermatol., 173(4): 1041-1049. https://doi.org/10.1111/ bjd.14045

7. Pappo A.S. (2003) Melanoma in children and adolescents. Eur. J. Cancer, 39(18): 2651-2661 https://doi.org/10.1016/j.ejca.2003.06.001

8. Braun R.P., Thomas L., Dusza S.W. et al. (2014) Dermoscopy of acral melanoma: A multicenter study on behalf of the international dermoscopy society. Dermatology, 227(4): 373-380. https://doi.org/10.1159/000356178

9. Phan A., Dalle S., Touzet S. et al. (2010) Dermoscopic features of acral lentiginous melanoma in a large series of 110 cases in a white population. Br. J. Dermatol., 162(4): 765-771. https:// doi.org/10.1111/j.1365-2133.2009.09594.x

\section{The BRAAFF index practical application in the diagnosis of acral melanocytic tumors}

\author{
M.S. Voloshynovych' ${ }^{1}$, A. Lallas' ${ }^{2}$, G.Ye. Girnyk' ${ }^{1}$ I.O. Blaga' \\ 'Ivano-Frankivsk National Medical University, Ukraine \\ ${ }^{2}$ Aristotle University of Thessaloniki, Greece
}

Abstract. Melanoma is one of the most dangerous tumors due to its ability to rapidly unpredictable metastasis. When the tumor is in open areas, the possibility of timely diagnosis increases, and with acral localization, melanoma for a long time may be neglected. To improve the prognosis of patients with acral melanoma, it is a prerequisite to ensure early diagnosis, which is the method of dermatoscopy. The role in the diagnosis of acral located pigmentation is to assess the features of the structure, which, unlike nevi of other localizations, is most often manifested in the form of patterns of parallel furrows, fibers, lattice-like pattern, and parallel ridge pattern. However, about $1 / 3$ of acral melanomas may consist of irregular diffuse pigments and other components, so additional criteria would be needed to reduce the likelihood of diagnostic errors. The result was the development, by a team of scientists from around the world, of the BRAAFF index, which is a score system for six variables that demonstrated the highest sensitivity and specificity for acral melanoma. Predictors such as irregular spotting, parallel ridge pattern, asymmetry of structures and colors give positive points, whereas parallel furrow and fibrillar pattern is negative. A diagnosis of acral melanoma is considered probable if the result of the calculations is $\geq 1$. Use of the BRAAFF index can greatly improve the quality and specificity of the examination when used in daily practice. It will also be useful for doctors who are just starting their careers and do not have sufficient experience to confidently prescribe therapeutic tactics. The publication provides clinical example of the use of an algorithmic approach for the management of patient with acral lesions on the skin.

Key words: melanoma, nevus, dermatoscopy.

\section{Information about the authors:}

Voloshynovych Marian S. - Candidate of Medical Sciences, Associate Professor at the Department of Dermatology and Venereology of the Ivano-Frankivsk National Medical University, Ukraine. ORCID ID: 0000-0001-7619-2289

Aimilios Lallas — PhD, Professor at the First Department of Dermatology of the Aristotle University of Thessaloniki, Greece. ORCID ID: 0000-0002-7193-0964

Girnyk Galyna Ye. - Candidate of Medical Sciences, Associate Professor at the Department of Dermatology and Venereology of the Ivano-Frankivsk National Medical University, Ukraine. ORCID ID: 0000-0002-9353-6490

Blaha Iryna 0. - Associate Lecturer of the Department of Dermatology and Venereology of the Ivano-Frankivsk National Medical University, Ukraine.

Address for correspondence:

Marian Voloshynovych

76018, Ivano-Frankivsk, Kropyvnytskogo str., 16

E-mail:mvoloshynovych@gmail.com 